\title{
Effect of systemic infections on glycylglycine absorption rate from the human jejunum in vivo
}

\author{
BY G. C. COOK \\ Department of Medicine, The University of Zambia, \\ $P O$ Box RW I Io, Lusaka, Zambia \\ (Received 8 October 1973-Accepted 29 November 1973)
}

\begin{abstract}
I. Using a double-lumen tube jejunal perfusion system, the rate of glycine absorption from a glycylglycine solution ( $50 \mathrm{mmol} / \mathrm{l}$ ) was measured in three groups of Zambian African subjects: in fifteen subjects there was no evidence of an infection (normal group); in eleven there was acute bacterial pneumonia and five had a chronic systemic infection.

2. Differences between the mean absorption rates for the three groups were not significant. 3. Glycine absorption rate has been shown previously to be increased in subjects with acute hacterial pneumonia. The present result provides further evidence that glycine and glycylglycine use separate transfer mechanisms in man, and suggests that dipeptide absorption rate is influenced to a lesser extent than that for free amino acids by systemic stimuli.
\end{abstract}

Absorption of glucose and D-xylose is impaired in subjects with acute pneumonia and other systemic bacterial infections (Cook, 1971, 1972a). In Zambian African subjects without such infections a significant inverse relationship between glucose absorption rate and serum total globulin and $\gamma$-globulin concentration has been shown (Cook, I973a). Conversely, in subjects with acute bacterial pneumonia glycine absorption rate is increased and, in Zambian African subjects without infections, is directly related to serum total globulin and $\gamma$-globulin concentration (Cook, 1973 $b$ ). Recent work suggests that absorption of peptides is of considerable quantitative importance in protein absorption in the rat (Crampton, Gangolli, Simson \& Matthews, I97I) and man (Nixon \& Mawer, I970). Rates of glycylglycine absorption have therefore been studied in vivo in subjects with and without systemic infections.

\section{EXPERIMENTAL}

Subjects. Details of thirty-one Zambian African men investigated are shown in Table I ; values for absorption rates of glycine from glycylglycine in eighteen of these subjects have been reported elsewhere (Cook, 1972b, 1973c). Many different Zambian tribes were represented (Brelsford, 1965). All subjects were in-patients at The University Teaching Hospital, Lusaka, and showed no clinical evidence of malnutrition or of gastrointestinal disease. All subjects gave their consent to the investigation after a full explanation of the procedure. Fifteen subjects showed no evidence of an infection (group I, normal), eleven (group 2) had acute bacterial pneumonia (lobar in eight of them), and five (group 3 ) had a chronic infection (pulmonary tuberculosis in one case and a severe Schistosoma haematobium infestation in four cases). Three subjects in group 2 were still pyrexial at the time of the investigation. Serum protein concentra- 
I64 G. C. $\mathrm{CoOK}$

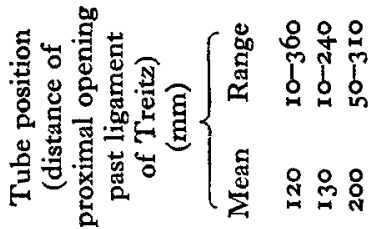

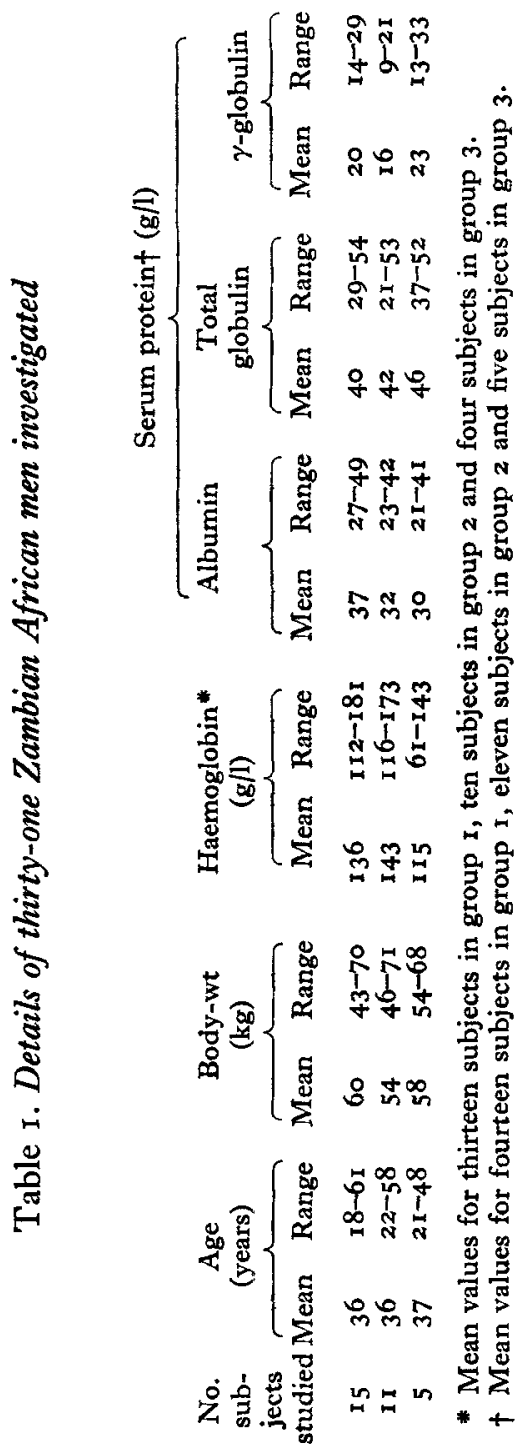

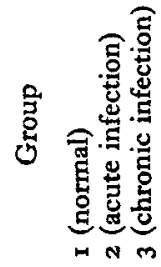


Table 2. Glycine and net water transfer rates from the glycylglycine solution (50 mmol/l) for the three groups of Zambian African men

\begin{tabular}{|c|c|c|c|c|c|c|}
\hline \multirow[b]{2}{*}{ Group } & \multicolumn{3}{|c|}{$\begin{array}{c}\text { Glycine absorption rate } \\
\text { (mg/min per } 300 \mathrm{~mm} \text { jejunum) }\end{array}$} & \multicolumn{3}{|c|}{$\begin{array}{l}\text { Net water transfer rate } \\
(\mathrm{ml} / \mathrm{min} \text { per } 300 \mathrm{~mm} \text { jejunum) }\end{array}$} \\
\hline & Mean & SEM & Range & Mean & SEM & Range \\
\hline $\begin{array}{l}\text { I (normal) } \\
2 \text { (acute } \\
\text { infection) }\end{array}$ & $\begin{array}{l}65 \cdot 7 \\
60 \cdot 6\end{array}$ & $\begin{array}{l}3 \cdot 6 \\
4 \cdot 6\end{array}$ & $\begin{array}{l}38-83 \\
30-84\end{array}$ & $\begin{array}{r}1 \cdot 5 \\
-0 \cdot 2\end{array}$ & $\begin{array}{l}0.4 \\
0.9\end{array}$ & $\begin{array}{l}-1 \cdot 7-3 \cdot 7 \\
-5 \cdot 2-4 \cdot 8\end{array}$ \\
\hline $\begin{array}{l}3 \text { (chronic } \\
\text { infection) }\end{array}$ & $68 \cdot 0$ & $4 \cdot 6$ & $55^{-82}$ & $2 \cdot 1$ & $I \cdot I$ & $-I \cdot 6-5 \cdot I$ \\
\hline
\end{tabular}

tions were determined as described by Cook (1973a). An investigation for the presence of stool parasites was done for some subjects in each of the three groups: in group I two subjects had hookworm and one had Strongyloides stercoralis, Giardia lamblia and hookworm $(\mathrm{n}=12)$; in group 2, five subjects had hookworm, one had hookworm and Schistosoma mansoni and one had Strongyloides stercoralis $(\mathrm{n}=\mathrm{II})$; in group 3, two subjects had hookworm $(\mathrm{n}=4)$. D-xylose tests (Cook, 1972a) were done in four subjects in group $\mathrm{I}$, five in group 2, and one in group 3 and, except in two subjects in group 2, all results were higher than $5 \mathrm{~g} / 5 \mathrm{~h}$, which is normal. The histology and dissecting-microscopic appearances of jejunal biopsy samples were determined in two subjects in group 1 , three in group 2, and one in group 3; all were normal for African subjects studied in Africa (Cook, Kajubi \& Lee, 1969).

Perfusion technique. A double-lumen tube technique was used to study jejunal glycylglycine absorption rate (Cook, $1972 b, 1973 b)$. Table I gives the position of the infusion opening of the tube, determined by radiology, in the three groups. The solution infused into the proximal jejunum contained $50 \mathrm{mmol}$ glycylglycine/1, $250 \mathrm{mmol}$ sodium chloride/ 1 and $5^{\circ} \circ \mathrm{g}$ polyethylene glycol (molecular weight 4000 )/ 1 as a nonabsorbable marker. The perfusion technique, analytical methods, and calculation of the results have been described previously (Cook, 1972b).

\section{RESULTS}

Table 2 summarizes the values obtained for rates of absorption of glycine from glycylglycine. The differences between the means for the three groups were not significant (by Student's $t$ test). No detectable abnormality was observed in two of the three subjects with the lowest absorption rates in the normal group and in the third subject, recovered acute gastro-enteritis was diagnosed. Table 2 also shows values for net water transfer from the glycylglycine solution; the differences between the means for the three groups are not significant (by Student's $t$ test). Table 3 summarizes tests of correlation (coefficient of linear correlation) between glycine absorption rate in the individual subjects and age, body-weight, haemoglobin, serum albumin, total globulin and $\gamma$-globulin and site of the infusion. The results are not statistically significant within the three groups or for the combined thirty-one subjects. 
Table 3. The coefficient of linear correlation $(\mathrm{r})^{*}$ between absorption rates of glycine from the glycylglycine solution (5० mmolll) and the results of clinical and biochemical investigations of thirty-one Zambian African men

\begin{tabular}{|c|c|c|c|c|c|c|c|c|}
\hline \multirow[b]{2}{*}{ Group } & \multirow{2}{*}{$\begin{array}{l}\text { No. } \\
\text { subjects } \\
\text { studied }\end{array}$} & \multirow[b]{2}{*}{$\begin{array}{c}\text { Age } \\
\text { (years) }\end{array}$} & \multirow[b]{2}{*}{$\begin{array}{c}\text { Body-wt } \\
\text { (kg) }\end{array}$} & \multirow{2}{*}{$\begin{array}{l}\text { Haemo- } \\
\text { globin } \dagger \\
(\mathrm{g} / \mathrm{l})\end{array}$} & \multicolumn{3}{|c|}{ Serum protein $f(g / l)$} & \multirow{2}{*}{$\begin{array}{c}\text { Tube } \\
\text { position } \\
\text { (distance } \\
\text { of } \\
\text { proximal } \\
\text { opening } \\
\text { past } \\
\text { ligament } \\
\text { of Treitz) } \\
\text { (mm) }\end{array}$} \\
\hline & & & & & Albumin & $\begin{array}{c}\text { Total } \\
\text { globulin }\end{array}$ & $\gamma$-globulin & \\
\hline$\stackrel{\text { I }}{\mathbf{I}, 2 \text { and } 3}$ & $\begin{array}{l}15 \\
3 \mathrm{I}\end{array}$ & $\begin{array}{l}+0.186 \\
-0.024\end{array}$ & $\begin{array}{l}+0.123 \\
+0.125\end{array}$ & $\begin{array}{l}-0.093 \\
+0.058\end{array}$ & $\begin{array}{l}+0.103 \\
+0.114\end{array}$ & $\begin{array}{l}+0.060 \\
+0.024\end{array}$ & $\begin{array}{l}+0.160 \\
+0.197\end{array}$ & $\begin{array}{l}-0.146 \\
+0.117\end{array}$ \\
\hline
\end{tabular}

\section{DISCUSSION}

The study shows that the absorption rate of the dipeptide glycylglycine from a $50 \mathrm{mmol} / \mathrm{l}$ solution is not significantly changed by acute and chronic systemic infections; nor is it significantly related to serum total globulin and $\gamma$-globulin concentrations. Acute lobar pneumonia in subjects very similar to those presently studied has been shown to increase the absorption rate of the amino acid glycine (Cook, 1973b); only one of the four subjects in the main part of that investigation was still pyrexial. This increase could be a compensatory mechanism for the hypercatabolic state associated with infection, or may be precipitated by the low dietary intake which often accompanies acute infections. Most results indicate that, in rats, short-term dietary restriction leads to increased amino acid absorption (Lis, Matthews \& Crampton, 1972), but the mechanism is unknown.

Separate mechanisms for amino acid and peptide transfer have been demonstrated in Escherichia coli (Payne, 1968), the rat (Lis, Crampton \& Matthews, 1972; Cheeseman \& Smyth, r973) and man (Asatoor, Cheng, Edwards, Lant, Matthews, Milne, Navab \& Richards, 1970; Hellier, Holdsworth, Perrett \& Thirumalai, 1972; Cook, I973 $c$ ). Recent results in the rat indicate that dietary changes produce different effects on absorption of free amino acids and peptides whether these substances are given alone or in the form of mixtures (Lis, Crampton et al. 1972; Lis, Matthews et al. 1972). The rate of absorption of dimethionine is influenced less than that of free methionine by dietary changes. Although short-term dietary restriction (for Io d) increases the absorption of methionine, that of the dipeptide is not significantly altered (Lis, Crampton et al. 1972). Whereas protein deprivation for $40 \mathrm{~d}$ decreases the absorption of an amino acid mixture in rats, absorption of a pancreatic hydrolysate is not altered (Lis, Matthews et al. 1972).

The present results, together with those previously obtained (Cook, $1973 b$ ), show that in man in vivo absorption rates of glycine and glycylglycine are influenced differently by acute bacterial infections. This is further evidence that amino acids and 
peptides use separate transfer mechanisms. Furthermore, glycylglycine absorption rate seems to be influenced to a lesser degree than glycine absorption rate by systemic stimuli. If the present observation has a practical implication, it is that protein supplements might be more rapidly absorbed when given as free amino acids than when given as peptides, in subjects with acute systemic bacterial infections.

I thank Dr N. O. Berg for jejunal histology reports and the Reverend W. H. Woodhouse for a generous gift to my research funds.

\section{REFEREN CES}

Asatoor, A. M., Cheng, B., Edwards, K. D. G., Lant, A. F., Matthews, D. M., Milne, M. D., Navab, F. \& Richards, A. J. (I970). Gut II, 380 .

Brelsford, W. V. (1965). The Tribes of Zambia. Lusaka, Zambia: Government Printer.

Cheeseman, C. I. \& Smyth, D. H. (I973). F. Physiol., Lond. 229, 45P.

Cook, G. C. (1971). Gut 12, 1001.

Cook, G. C. (1972a). Am. F. clin. Nutr. 25, 490.

Cook, G. C. $(1972 b)$. Clin. Sci. 43, 443 .

Cook, G. C. (1973a). Nature, Lond. 241, 284.

Cook, G. C. $(1973 b)$. Br. F. Nutr. 29, 377.

Cook, G. C. (1973C). Br. Y. Nutr. 30, 13.

Cook, G. C., Kajubi, S. K. \& Lee, F. D. (r969). Y. Path. 98, 157.

Crampton, R. F., Gangolli, S. D., Simson, P. \& Matthews, D. M. (1971). Clin. Sci. 41, 409.

Hellier, M. D., Holdsworth, C. D., Perrett, D. \& Thirumalai, C. (1972). Clin. Sci. 43, 659.

Lis, M. T., Crampton, R. F. \& Matthews, D. M. (1972). Br. F. Nutr. 27, 159.

Lis, M. T., Matthews, D. M. \& Crampton, R. F. (1972). Br. F. Nutr. 28, 443.

Nixon, S. E. \& Mawer, G. E. (1970). Br. $\mathscr{Y}$. Nutr. $24,241$.

Payne, J. W. (1968). F. biol. Chem. 243, 3395. 